Young Min Choi · Jong Kwan Jun · Jin Choe

Doyeong Hwang • Sung Hyo Park • Seung Yup Ku

Daehee Kang • Jung Gu Kim • Shin Yong Moon

Jin Yong Lee

\title{
Association of the vitamin D receptor start codon polymorphism (Fokl) with bone mineral density in postmenopausal Korean women
}

\begin{abstract}
We undertook this study in order to examine the association between bone mineral density (BMD) and a polymorphism at the first of two potential translation initiation codons in the vitamin $\mathrm{D}$ receptor $(V D R)$ gene. This polymorphism was detected by restriction fragment length polymorphism analysis, using polymerase chain reaction (PCR) and the restriction endonuclease FokI. The $f$ allele indicates the presence of the FokI site, and the $F$ allele its absence. The FokI genotype was determined in 174 postmenopausal Korean women, aged 43-71 years. The distribution of FokI genotypes in Koreans was found not to differ significantly from those found in Caucasians and Japanese, although it does differ significantly from that found in the black American population. We observed a significant association between the FokI polymorphism and lumbar BMD; $P=0.048$, analysis of covariance [ANCOVA], but no association with femoral neck BMD $(P=0.505$, ANCOVA $)$. Those with the $f f$ genotype had a $13.3 \%$ lower BMD in the lumbar spine than the $F F$ subjects. In addition, a significantly higher prevalence of the $f f$ genotype was observed in osteoporotic compared with osteopenic or normal women $\left(P=0.036, \chi^{2}\right.$ test $)$. These data suggest that the $f f$ genotype of the $V D R$ gene correlates with decreased BMD in the lumbar spine in postmenopausal Korean women.
\end{abstract}

Key words Bone mineral density $\cdot$ FokI $\cdot$ DNA polymorphism $\cdot$ Vitamin D receptor

Y.M. Choi $(\bowtie) \cdot$ J.K. Jun $\cdot$ J. Choe $\cdot$ D. Hwang $\cdot$ S.H. Park ·

S.Y. Ku $\cdot$ J.G. Kim $\cdot$ S.Y. Moon · J.Y. Lee

Department of Obstetrics and Gynecology, College of Medicine,

Seoul National University, 28 Yungun-dong, Chongno-ku, Seoul 110-

744 , Korea

Tel. +82-2-760-2385; Fax +82-2-760-2842

e-mail: ymchoi@plaza.snu.ac.kr

D. Kang

Department of Preventive Medicine, College of Medicine, Seoul

National University, Seoul, Korea

Y.M. Choi · S.Y. Moon

The Institute of Reproductive Medicine and Population, Medical

Research Center, Seoul National University, Seoul, Korea

\section{Introduction}

Bone mineral density (BMD), the major determinant of osteoporotic fracture risk, is known to be under strong genetic determination (Kelly et al. 1995). Since the initial report of an association of vitamin $\mathrm{D}$ receptor $(V D R)$ polymorphism, defined by the restriction endonucleases ApaI, BsmI, and TaqI, with BMD (Morrison et al. 1994), many subsequent studies of a variety of populations have reached divergent conclusions, with some investigators finding an association between this polymorphism and BMD (Eiseman 1995), while others have not (Peacock 1995).

Cloning of the VDR gene revealed two potential translation initiation codons (ATG) in exon 2 (Baker et al. 1988). A T/C polymorphism (ATG $\rightarrow$ ACG) was discovered at the first ATG (Saijo et al. 1991), and has been defined using Fok I restriction endonuclease (Gross et al. 1996). Individuals who have an ACG codon, indicated by the $F$ allele, instead of the first ATG codon probably initiate from the second ATG codon, and have a VDR protein three amino acids shorter. This structural difference, caused by the two alleles, may affect the function of the VDR protein. In this regard, it has recently been demonstrated that the shorter form of VDR gives an approximately 1.7-fold greater transcriptional activation in transfected HeLa cells than the longer form, which suggests a difference in the biological activity of the two VDR isoforms (Arai et al. 1997).

During the past 4 years, several studies have examined the association between BMD and a start codon polymorphism of the $V D R$ gene in pre- and postmenopausal women. The initial study by Gross et al. (1996), conducted in postmenopausal Caucasian Mexican-American women, showed a $12.8 \%$ lower lumbar spine BMD in $15 f f$ homozygous women when compared with $37 \mathrm{FF}$ homozygous women, and also showed an increased bone loss rate from the femoral neck in $f f$ women when compared with $F F$ women, as observed during a 2-year period. Another study, of postmenopausal Italian women, also showed a weak association between the FokI polymorphism and lumbar 
BMD $(P=0.060)$, but no association with femoral neck BMD (Gennari et al. 1999).

Studies of premenopausal women have shown conflicting results. One study (Arai et al. 1997), conducted in premenopausal Japanese women, reported a $10.7 \%$ lower lumbar spine BMD in $16 \mathrm{ff}$ homozygous women than in $30 \mathrm{FF}$ homozygous women. However, another study (Eccleshall et al. 1998), conducted in premenopausal French women, reported the lack of an association between the FokI genotype and BMD.

In the present study, we examined the relationship of the Fok I polymorphism with BMD, in a group of 174 postmenopausal Korean women.

\section{Subjects and methods}

Subjects

A total of 174 unrelated postmenopausal women who had attended the menopause clinic at Seoul National University Hospital between January 1998 and December 1999, because of possible postmenopausal symptoms or for the evaluation of osteoporotic risk, were recruited for this study. All subjects were Korean, and were enrolled in this study after individually giving their informed consent. Women with a history of bone disease other than primary osteoporosis, or those who had used drugs with activity in bone, or drugs that could potentially affect bone metabolism, prior to BMD measurement were excluded from this study.

The age range of the enrolled women was 43-71 years, with a mean $( \pm S D)$ age of $55.1 \pm 6.0$ years. On the basis of BMD measurements taken in the lumbar spine $\left(\mathrm{L}_{2}-\mathrm{L}_{4}\right)$ and femur neck, and according to the World Health Organization criteria (Kanis et al. 1994), 66 (37.9\%) of the 174 subjects displayed osteoporosis, 62 (35.6\%) had osteopenia, and $46(26.4 \%)$ were normal. The general characteristics of the subjects are presented in Table 1.

\section{Bone densitometry}

BMD was measured in the lumbar spine $\left(\mathrm{L}_{2}-\mathrm{L}_{4}\right)$, femoral neck, trochanter, and Ward's triangle, using a Lunar DPXL dual-energy X-ray absorptiometer (Lunar Radiation, Madison, WI, USA). A BMD measurement was available for all 174 studied women. The in-vivo coefficient of variation was $1.4 \%$ for the lumbar spine, $2.1 \%$ for the femoral

Table 1. Baseline characteristics of the subjects in this study

\begin{tabular}{|c|c|c|c|}
\hline Genotype & $F F$ & $F f$ & $f f$ \\
\hline Subjects $(n)$ & 58 & 88 & 28 \\
\hline Age (years) & $54.6 \pm 6.1$ & $55.1 \pm 5.8$ & $55.7 \pm 6.8$ \\
\hline Years since menopause & $4.6 \pm 4.6$ & $5.9 \pm 6.6$ & $6.6 \pm 6.5$ \\
\hline Weight (kg) & $59.1 \pm 8.2$ & $57.4 \pm 8.6$ & $55.6 \pm 8.6$ \\
\hline Height $(\mathrm{cm})$ & $156.5 \pm 4.4$ & $154.8 \pm 5.3$ & $154.6 \pm 5.3$ \\
\hline
\end{tabular}

Values are expressed as means $\pm \mathrm{SD}$ neck, $1.1 \%$ for the trochanter, and $2.1 \%$ for Ward's triangle.

\section{Biochemical markers of bone turnover}

Blood and urine samples were collected in the morning for the measurement of bone turnover markers. Samples obtained after or during the use of any drugs with activity in bone were excluded from the analysis. Measurements of urinary deoxypyridinoline (DPYD), urinary cross-linked N-telopeptide of type I collagen (NTX), and serum osteocalcin were available for 60,47 , and 110 subjects, respectively. Urinary deoxypyridinoline was measured using enzyme-linked immunosorbent assay (ELISA) kits (Metra Biosystems, Mountain View, CA, USA). Urinary NTX was also determined using ELISA kits (Osteomark, Ostex International, Seattle, WA, USA). The values for DPYD and NTX in the urine samples were expressed per mmol of urinary creatinine. The minimum detection limits were $1.1 \mathrm{nmol} / \mathrm{mmol}$ creatinine for DPYD and $1 \mathrm{nmol} / \mathrm{mmol} \mathrm{crea}-$ tinine for NTX, respectively. Intra- and inter-assay variations for DPYD were $4.3 \%$ and $4.6 \%$, respectively. For NTX, the corresponding figures were $7.6 \%$ and $4.0 \%$. Serum osteocalcin was measured using competitive radio immunoassay (RIA) kits (Techno Genetics, Milan, Italy). The minimum detection limit was $0.1 \mathrm{nmol} / \mathrm{l}$. Intra- and inter-assay variations for osteocalcin were $4.0 \%$ and $5.1 \%$, respectively.

\section{Genotyping}

In all subjects, genomic DNA was extracted from peripheral blood samples, with the Wizard genomic DNA purification kit (Promega, Madison, WI, USA). FokI start codon polymorphisms were determined according to previously described methods (Gross et al. 1996), with minor modifications. Briefly, the 265-bp fragment of exon 2 was amplified by polymerase chain reaction (PCR), using the primers $5^{\prime}$ AGCTGGCCCTGGCACTGACTCTGCTCT-3' and ' 5'ATGGAAACACCTTGCTTCTTCTCCCTC-3'. PCR was performed by adding $0.1-0.5 \mu \mathrm{g}$ of DNA to $50 \mu \mathrm{l}$ of PCR reaction mixture (final concentration, $50 \mathrm{mM} \mathrm{KCl}, 10 \mathrm{mM}$ Tris $\mathrm{HCl}(\mathrm{pH} 8.3), 1.5 \mathrm{mM} \mathrm{MgCl}_{2}, 0.01 \%$ [w/v] gelatin, $50 \mu \mathrm{M}$ each dNTP, and $0.5 \mu \mathrm{M}$ of each primer and $1 \mathrm{U}$ of Taq polymerase). The PCR products were digested with FokI restriction endonuclease (New England Biolabs, Beverly, MA, USA) at $37^{\circ} \mathrm{C}$ for $4 \mathrm{~h}$, and then electrophoresed through a $3 \%$ agarose gel, containing ethidium bromide. The presence of the restriction site, which generates two fragments, of $196 \mathrm{bp}$ and $69 \mathrm{bp}$, was indicated by $f$, while its absence, resulting in a single uncut 265-bp fragment, was indicated by $F$. Subjects were scored as $f f$ homozygotes, $F f$ heterozygotes, and $F F$ homozygotes according to the digestion pattern.

\section{Statistical analysis}

All results are expressed as means \pm SD. Statistical analyses were performed using SPSS Ver8.0 (Manugistic, 
Rockville, MA, USA). Subject characteristics, such as age, years since menopause, weight, and height, in the FokI genotype groups were compared by analysis of variance. $\mathrm{BMD}$ and bone turnover markers for these groups were compared by analysis of covariance (ANCOVA). The following covariates were considered for ANCOVA: age, years since menopause, weight, and height. The frequency distributions of genotypes in the osteoporotic, osteopenic, and normal groups were compared using a $\chi^{2}$ test. Given an alpha level of 0.05 , this study had $90 \%$ statistical power to detect BMD differences between homozygous groups, of about $11.3 \%$ in the lumbar spine, $11.7 \%$ in the femoral neck., $15.9 \%$ in Ward's triangle, and $11.2 \%$ in the trochanteric region. A $P$ value of less than 0.05 was considered significant for all analyses.

\section{Results}

FokI genotyping was performed in a group of 174 unrelated Koreans. The frequencies of the FokI genotypes were $33.3 \%$ for $F F, 50.6 \%$ for $F f$, and $16.1 \%$ for $f f$. The genotype distribution was in Hardy-Weinberg equilibrium (given the expected frequencies of the $F F, F f$, and $f f$ genotypes of $34.5 \%, 48.3 \%$, and $17.2 \%$ respectively). There were no significant differences between the FokI genotype groups for age, years since menopause, height, or weight (Table 1).

As shown in Table 2, the BMD analysis after adjustments for potential confounding factors, such as age, years since menopause, height, and weight, revealed a significant association between lumbar spine BMD and the FokI genotype $(P=0.048$, ANCOVA $)$. Individuals with the $f f$ genotype had a $13.3 \%$ lower BMD in the lumbar spine than those with the $F F$ genotype $(P=0.022)$. The analysis of $\mathrm{Z}$ score values, instead of adjusted BMD values, also showed a significant association between the FokI genotype and BMD in the lumbar spine $(P=0.042$, ANCOVA). Additionally, the trochanter BMD, analyzed by Z-score, showed a weak association with the FokI genotype $(P=0.080$, ANCOVA). However, no significant association was observed between the FokI genotype and BMD in the femur neck or Ward's triangle. There were no differences between the genotype groups in terms of measurements of serum osteocalcin, urinary DPYD, or urinary NTX.

Genotype determinants for osteoporotic, osteopenic, and normal groups are summarized in Table 3. We observed a significant three-fold increased prevalence of the $f f$ genotype in osteoporotic women compared with normal women $\left(P=0.036, \chi^{2}\right.$ test $)$.

\section{Discussion}

The distribution of the FokI genotypes in the Korean population is very similar to what was previously described in Mexican-American (Gross et al. 1996), Japanese (Arai et al. 1997), white North American (Harris et al. 1997), French (Eccleshall et al. 1998), and Swiss (Ferrari et al. 1998b)

Table 2. Adjusted bone mineral density (BMD) and bone turnover markers according to FokI genotypes

\begin{tabular}{|c|c|c|c|c|}
\hline \multirow{2}{*}{$\begin{array}{l}\text { BMD or bone turnover } \\
\text { markers }^{\mathrm{a}}\end{array}$} & \multicolumn{3}{|l|}{ Genotype } & \multirow[b]{2}{*}{$P$ value $^{\mathrm{b}}$} \\
\hline & $F F$ & $F f$ & $f f$ & \\
\hline Lumbar spine $\left(\mathrm{g} / \mathrm{cm}^{2}\right)$ & $1.008 \pm 0.187$ & $0.963 \pm 0.181$ & $0.874 \pm 0.162$ & 0.048 \\
\hline Lumbar spine (Z-score) & $-0.510 \pm 1.300$ & $-0.823 \pm 1.287$ & $-1.415 \pm 1.043$ & 0.042 \\
\hline Femoral neck $\left(\mathrm{g} / \mathrm{cm}^{2}\right)$ & $0.826 \pm 0.179$ & $0.796 \pm 0.149$ & $0.754 \pm 0.135$ & 0.505 \\
\hline Femoral neck (Z-score) & $0.340 \pm 1.176$ & $0.137 \pm 1.008$ & $-0.118 \pm 0.867$ & 0.508 \\
\hline Ward's triangle $\left(\mathrm{g} / \mathrm{cm}^{2}\right)$ & $0.660 \pm 0.186$ & $0.630 \pm 0.157$ & $0.585 \pm 0.158$ & 0.464 \\
\hline Ward's triangle (Z-score) & $-0.385 \pm 1.140$ & $-0.523 \pm 0.998$ & $-0.728 \pm 0.838$ & 0.686 \\
\hline Trochanter $\left(\mathrm{g} / \mathrm{cm}^{2}\right)$ & $0.720 \pm 0.136$ & $0.700 \pm 0.125$ & $0.642 \pm 0.125$ & 0.150 \\
\hline Trochanter (Z-score) & $0.228 \pm 1.051$ & $-0.044 \pm 1.010$ & $-0.456 \pm 0.881$ & 0.080 \\
\hline DPYD (nmol/mmol urinary creatinine) & $6.4 \pm 5.2$ & $8.0 \pm 4.1$ & $6.0 \pm 2.2$ & 0.515 \\
\hline NTX (nmol/mmol urinary creatinine) & $112.4 \pm 110.7$ & $117.1 \pm 107.2$ & $52.5 \pm 16.2$ & 0.639 \\
\hline Osteocalcin $(\mathrm{ng} / \mathrm{ml})$ & $8.4 \pm 4.7$ & $7.8 \pm 4.1$ & $7.3 \pm 2.3$ & 0.495 \\
\hline
\end{tabular}

Values are expressed as means $\pm \mathrm{SD}$

DPYD, deoxypyridinoline; NTX, cross-linked N-telopeptide of type I collagen

${ }^{a}$ Adjusted values for age, height, weight, and years since menopause, using analysis of covariance (ANCOVA)

${ }^{\mathrm{b}} P$ value from ANCOVA

Table 3. Distribution of FokI genotypes in osteoporotic, osteopenic, and normal subjects

\begin{tabular}{llllll}
\hline & \multicolumn{2}{l}{ Subjects } & & & \\
\cline { 2 - 5 } Genotype & Normal & Osteopenic & Osteoporotic & & $\chi^{2}$ \\
\hline$F F$ & $26(40.0 \%)$ & $20(32.8 \%)$ & $12(25.0 \%)$ & 2.81 & 0.246 \\
$F f$ & $33(50.8 \%)$ & $32(52.5 \%)$ & $23(47.9 \%)$ & 0.22 & 0.894 \\
$f f$ & $6(9.2 \%)$ & $9(14.8 \%)$ & $13(27.1 \%)$ & 6.64 & 0.036 \\
\hline${ }^{a} P$ value from $\chi^{2}$ test & & &
\end{tabular}


populations. However, it was significantly different from that described in a black North American population (Harris et al. 1997).

A previous report on the relationship between $V D R$ polymorphism, defined by restriction endonuclease BsmI, and BMD in a Korean population failed to show a significant association (Lim et al. 1995). In contrast, the present study showed a significant association between the FokI polymorphism and lumbar spine BMD in postmenopausal Korean women. In the Korean population, $f f$ homozygous women demonstrated a $13.3 \%$ lower lumbar spine BMD than $F F$ homozygous women. These results are consistent with an initial report on postmenopausal Caucasian Mexican-American women, which showed a $12.8 \%$ lower lumbar spine BMD in $15 \mathrm{ff}$ homozygous women than in 37 $F F$ homozygous women (Gross et al. 1996). Moreover, our results are also in accord with a previous study in postmenopausal Italian women, which demonstrated a weak association between the FokI polymorphism and lumbar BMD ( $P$ $=0.06)$ but no association with femoral neck BMD (Gennari et al. 1999).

Our findings that BMD in the trochanteric region, but not in the femoral neck, also showed a weak association with the FokI genotype, suggest that the effect of the FokI genotype on BMD may be more evident in trabecular bone than in cortical bone. As noted previously (Kelly et al. 1995), a heritable effect on peak bone mass may be more important in the lumbar spine, whereas the heritable effect in the femoral neck may be more influenced by environmental factors, such as calcium intake or vitamin D status.

A recent study reported that the effect of the FokI genotype on lumbar spine BMD was more pronounced during the first 5 years of menopause (Gennari et al. 1999). This suggests that the BMD differences among the FokI VDR genotypes could be blunted over time, as occurs with Bsm I $V D R$ gene polymorphisms (Riggs et al. 1995; Ferrari et al. 1998a). Thus, we believe it likely that the BMD differences in the lumbar spine are attributable, at least in part, to the effect of the FokI genotype on peak bone mass. The lower $\mathrm{BMD}$ in the lumbar spine in premenopausal Japanese women with the $f f$ genotype (Arai et al. 1997) further supports this hypothesis. However, other studies of premenopausal women have failed to show an association between the FokI genotype and lumbar spine BMD, in the French (Eccleshall et al. 1998) and white American populations (Harris et al. 1997). In particular, the latter study showed a significantly lower BMD in the femoral neck, not in the lumbar spine, in $f f$ subjects than in $F F$ or $F f$ subjects (Harris et al. 1997).

These conflicting results regarding the relationship of the FokI polymorphism with BMD, as mentioned above, may be partly due to ethnic origin or environmental factors, such as dietary calcium intake (Ferrari et al. 1998b). Thus, further studies of various ethnic groups are required to elucidate the role of the FokI polymorphism in BMD. In conclusion, we observed a significant association between FokI genotype and BMD in the lumbar spine in postmeno- pausal Korean women, a finding which is consistent with the findings reported in postmenopausal Caucasian women (Gross et al. 1996) and in premenopausal Japanese women (Arai et al. 1997).

\section{References}

Arai H, Miyamoto K, Taketani Y, Yamamoto H, Iemori Y, Morita K, Tonai T, Nishisho T, Mori S, Takeda E (1997) A vitamin D receptor gene polymorphism in the translation initiation codon: effect on protein activity and relation to bone mineral density in Japanese women. J Bone Miner Res 12:915-921

Baker AR, McDonnell DP, Hughes M, Crisp TM, Mangelsdorf DJ, Haussler MR, Pike JW, Shine J, O'Malley BW (1988) Cloning and expression of full-length cDNA encoding human vitamin D receptor. Proc Natl Acad Sci USA 85:3294-3298

Eccleshall TR, Garnero P, Gross C, Delmas PD, Feldman D (1998) Lack of correlation between start codon polymorphism of the vitamin D receptor gene and bone mineral density in premenopausal French women: the OFELY study. J Bone Miner Res 13:31-35

Eisman JA (1995) Vitamin D receptor gene alleles and osteoporosis: an affirmative view. J Bone Miner Res 10:1289-1293

Ferrari S, Rizzoli R, Slosman DO, Bonjour JP (1998a) Do dietary calcium and age explain the controversy surrounding the relationship between bone mineral density and vitamin D receptor gene polymorphisms? J Bone Miner Res 13:363-370

Ferrari S, Rizzoli R, Manen D, Slosman D, Bonjour JP (1998b) Vitamin D receptor gene start codon polymorphisms (FokI) and bone mineral density: interaction with age, dietary calcium, and $3^{\prime}$-end region polymorphisms. J Bone Miner Res 13:925-930

Gennari L, Becherini L, Mansani R, Masi L, Falchetti A, Morelli A, Colli E, Gonnelli S, Cepollaro C, Brandi ML (1999) FokI polymorphism at translation initiation site of the vitamin $\mathrm{D}$ receptor gene predicts bone mineral density and vertebral fractures in postmenopausal Italian women. J Bone Miner Res 14:1379-1386

Gross C, Eccleshall TR, Malloy PJ, Villa ML, Marcus R, Feldman D (1996) The presence of a polymorphism at the translation initiation site of the vitamin $\mathrm{D}$ receptor gene is associated with low bone mineral density in postmenopausal Mexican-American women. J Bone Miner Res 11:1850-1855

Harris SS, Eccleshall TR, Gross C, Dawson-Hughes B, Feldman D (1997) The vitamin D receptor start codon polymorphism (FokI) and bone mineral density in premenopausal American black and white women. J Bone Miner Res 12:1043-1048

Kanis JA, Melton LJ 3rd, Christiansen C, Johnston CC, Khaltaev N (1994) The diagnosis of osteoporosis. J Bone Miner Res 9:1137-1141

Kelly PJ, Morrison NA, Sambrook PN, Nguyen TV, Eisman JA (1995) Genetic influences on bone turnover, bone density and fracture. Eur J Endocrinol 133:265-271

Lim SK, Park YS, Park JM, Song YD, Lee EJ, Kim KR, Lee HC, Huh KB (1995) Lack of association between vitamin D receptor genotypes and osteoporosis in Koreans. J Clin Endocrinol Metab 80:3677-3681

Morrison NA, Qi JC, Tokita A, Kelly PJ, Crofts L, Nguyen TV, Sambrook PN, Eisman JA (1994) Prediction of bone density from vitamin D receptor alleles. Nature 367:284-287

Peacock M (1995) Vitamin D receptor gene alleles and osteoporosis: a contrasting view. J Bone Miner Res 10:1294-1297

Riggs BL, Nguyen TV, Melton LJ 3rd, Morrison NA, O'Fallon WM, Kelly PJ, Egan KS, Sambrook PN, Muhs JM, Eisman JA (1995) The contribution of vitamin $\mathrm{D}$ receptor gene alleles to the determination of bone mineral density in normal and osteoporotic women. J Bone Miner Res 10:991-996

Saijo T, Ito M, Takeda E, Huq AH, Naito E, Yokota I, Sone T, Pike JW, Kuroda Y (1991) A unique mutation in the vitamin D receptor gene in three Japanese patients with vitamin D-dependent rickets type II: utility of single-strand conformation polymorphism analysis for heterozygous carrier detection. Am J Hum Genet 49:668-673 